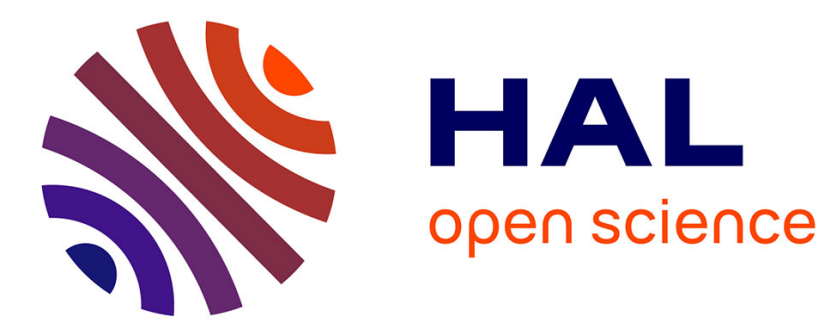

\title{
Do the Rite Thing: Religious Civil Unions in Vermont
}

\author{
Baptiste Coulmont
}

\section{To cite this version:}

Baptiste Coulmont. Do the Rite Thing: Religious Civil Unions in Vermont. Social Compass, 2005, 52 (2), pp.225-239. 10.1177/0037768605052604 . halshs-00768607

\section{HAL Id: halshs-00768607 https://shs.hal.science/halshs-00768607}

Submitted on 22 Dec 2012

HAL is a multi-disciplinary open access archive for the deposit and dissemination of scientific research documents, whether they are published or not. The documents may come from teaching and research institutions in France or abroad, or from public or private research centers.
L'archive ouverte pluridisciplinaire HAL, est destinée au dépôt et à la diffusion de documents scientifiques de niveau recherche, publiés ou non, émanant des établissements d'enseignement et de recherche français ou étrangers, des laboratoires publics ou privés. 


\section{Do the Rite Thing: Religious Civil Unions in Vermont}

Published (with revision) as :

Coulmont, Baptiste (2005), « Do the Rite Thing: Religious Civil Unions in Vermont ». Social

Compass, 2005, 52[2], p.225-239.

Abstract: Vermont, one of the smallest US states, implemented in 2000 a new form of recognized partnership for same-sex couples. A "civil union" gives the couple that contracts it the same benefits a marriage gives to a heterosexual couple. As with a marriage, ministers (pastors, priests, rabbis) are agents of the state when performing a civil union.

Following an intense cultural conflict, the implementation of civil unions was simultaneous with a speedy accommodation on the part of the churches. I will provide two explanations for this phenomenon. First, civil unions of the religious type, understood as a religious consumption, provide incentives for an economic routinization. Second, I focus on the work of the ministers: through various appeals to the legal order, they try to find ways to perform same-sex wedding ceremonies.

Résumé: En 2000, le Vermont, un petit État américain, créa les « unions civiles », qui donne aux couples du même sexe les mêmes droits que les couples mariés. Pasteurs, prêtres et rabins sont autorisés à célébrer ces unions au nom du pouvoir civil, de la même manière qu'un mariage peut être célébré par un membre du clergé ou un juge de paix. A la suite d'un intense conflit, la mise en place des unions civiles a été accompagnée d'une rapide accommodation religieuse. Nous apportons deux explication à ce phénomène. Tout d'abord, les unions civiles "religieuses", comprises comme une consommation de religion, présentent des incitations à une routinisation économique. Ensuite, en s'intéressant au travail des pasteurs, nous montrons que ces derniers, au moyen de références à la légalité, tentent de trouver les moyens de célébrer des unions civiles.

Keywords: marriage, homosexuality, religion, civil union, Vermont Mots-clés: mariage, homosexualité, religion, union civile, Vermont 
State and church in the United States of America are quite well separated, and ministers are not agents of the state. Except in the marriage business. ${ }^{1}$ Ministers are allowed to certify marriage licenses, and the law considers that they are "agents of the state". The author of a legal handbook for the clergy (Couser, 1993: 78-79) wrote:

In performing marriages, clergy are considered to function as public officers for limited purposes. [...] It seems to have been universally accepted and apparently never challenged as a violation of the Establishment Clause. In this particular area, a religious ceremony results in a valid civil marriage that carries rights and responsibilities enforceable by the secular legal system.

In 2000, the Vermont legislature upheld this "tradition" when it created "civil unions", which gave all state-related benefits of marriage to gay or lesbian couples (15 V.S.A. $\S 1204)$.

Gay and lesbian organizations have struggled for more than ten years to gain access to marriage. The U.S. Protestant churches have been shaken by a parallel struggle for the right of gay and lesbian couples to be married in the church. Liberal pastors or rabbis have signed open letters and petitions to push for (civil) same-sex marriage. But nobody has ever asked the state to allow ministers to perform civilly-sanctioned ceremonies. That is, nonetheless, what the Vermont legislature gave to Vermont churches. Same-sex weddings have been, in Vermont, "statified": "holy unions", "ceremonies of commitments", "covenants in love" are now "civil unions".

This "statification" followed a passionate mobilization in favor of or opposed to same-sex marriage. A continuing religious controversy was expected, but eighteen months after the first civil union, during a fieldwork in Vermont, I found a widespread accommodation. This article is then focused on how mobilization and controversy (the first part of this article) gave birth to routine: through commodification and the entry of religious civil union into the economic realm (second part) and through an appeal to the legal order and/or the tradition.

\section{The path to civil union}

\section{Gay and lesbian involvement}

The success of the same-sex marriage movement stems out of a strongly organized network: "one thing that distinguishes Vermont is the remarkable amount of planning and coordination 
which preceded and accompanied the push for equal marriage rights" (Johnson, 2000: 26) a law professor wrote in the Vermont Law Review. Around 1983, with the first Lesbian and Gay Pride Parade in Burlington, the Vermont Coalition for Lesbian and Gay Rights (VCLGR) was founded and got access to the governor (Conroy, 1990 and Bernstein, 2002). In 1990, a hate crime law was approved by the legislature. In 1992, an anti-discrimination law protecting gay and lesbian people at work was passed. In 1993, the Vermont Supreme Court decided that a woman could adopt the child conceived by her same-sex partner. After this date, the VCLGR focused its efforts on same-sex marriage. In 1995, the Vermont Freedom to Marry Task Force was created by two lawyers, Susan Murray and Beth Robinson. This Task Force was instrumental in the 1997 lawsuit that ended with the Supreme Court decision in Baker v. State (744 A2d 864 [Vt 1999]) according to which Vermont shall give same-sex couples the benefits of marriage.

This movement described homosexuality as mild, tamed, civilized: the couples involved in the lawsuit against the state of Vermont were older couples, they were Vermonters and not "flatlanders" (Baker, who gave his name to the lawsuit, is the descendant of a local revolutionary hero), one of them had a child... Sociologist Mary Bernstein spoke of "a discrete and insular minority" (Bernstein, 2002) that followed "strategies that emphasized similarities to the straight public and the incremental nature of policy reform" (Bernstein, 1997: 552).

\section{The involvement of churches}

Vermont churches were involved in the civil union debate. The Vermont Freedom to Marry Task Forces relied on liberal-leaning congregations to inform Vermonters: from 1995 on, all over the state, meetings were organized, in church buildings, to explain the claims of the Task Force.

At the onset of the lawsuit, between 1997 and 1999, several churches submitted "Friends of the Court" Briefs to the Supreme Court. An organization called vows, Vermont Organization for the Wedding of the Same gender, filed a brief with seven liberal congregations: two Unitarian churches, one Presbyterian congregation, two Quaker meetings, one United Church of Christ, and one Jewish synagogue. Opposed to this brief, the Roman Catholic Diocese of Vermont and the Latter-Day Saints Church of Vermont submitted a common brief, in which both churches struggled to find a unified marriage theology to counter same-sex marriage. 
This involvement was mild compared to what followed the Supreme Court decision (in December 1999). From January to May 2000, the legislature drafted and voted the civil union law, and a statewide debate took place. Newspapers were filled with letters to the editor (some days, letters to the Brattleboro Reformer - a small newspaper in Southern Vermont - were so numerous that they took up to four times the usual space). Religious themes were heavily present. Newspaper articles and letters to the editors revealed an opposition to same-sex marriage based on religious arguments. The Catholic diocese, with the help of evangelical pastors, organized several demonstrations in Montpelier, the state capital, to voice their anger at same-sex marriage.

In May 2000, the Vermont legislature chose to create a middle way between non-recognition and full marriage: civil unions. This compromise was accepted by the couples and the Vermont Freedom to Mary Task Force. Less obviously, the churches seemed to accept this compromise. I will outline here two different explanations: the first one contends that religious "civil unions" are to be understood as a religious consumption, the second one argues that various contextual elements and strategic steps were used by ministers to perform civil unions.

\section{Civil unions as a new business?}

One way to end a controversy of this type is through a "pragmatic" or "market oriented" move: because civil unions were a source of income for some ministers, they had an incentive to perform them. This explanation is insufficient, but is a first analytical step. In fact, this is a two-step reasoning: a theoretical one (based on the "rational choice theory"), and a descriptive one (based on the scholarship of commodification).

\section{Theory: Is marriage a religious consumption?}

If one has to consider that civil unions create a market, let me consider that religion itself is, for the purpose of our research, a market. The rational choice theory applied to the sociology of religion gave birth to a conception of religious involvement as an economic investment. But rational choice theorists' religion is a form of evangelical religion: personal beliefs and the intensity of these beliefs are the core of religiosity. On one hand, personal acts such as prayers are signs of religious involvement, on the other hand, the choice of a religious marriage alone is not seen as a sign of religiosity. 
In a recent article inspired by such a theory, Darren Sherkat concluded that men who declared they had sexual intercourse with other men also declared being more "religious" than women who declared having sexual intercourse with other women, and than "heterosexual" men. Sherkat's conclusions are interesting, but based on a very small number (99 "lesbians", 149 "gay males" compared to 5,620 "female heterosexuals").

I can use the civil union licenses to moderate Sherkat's finding: they include some social data on the people who chose to have a civil union (age, education, race, state of residence, number of previous marriages, type of ceremony).

\section{TABLE 1 ABOUT HERE}

14.6 per cent of the women couples chose to have a religious civil union as compared to 13.6 per cent of the male couples: lesbian women seem to be at least as religious as gay men, even if they contract twice as many civil unions. However gay and lesbian couples seem to be much less "religious" than heterosexual couples. Whereas 43 per cent of heterosexual couples chose to have a religious wedding, only 14.3 per cent of same-sex couples chose to have a religious civil union. How is it possible to understand this discrepancy?

First, civil union - a new religious and civil category - has still to get the traditional appeal that marriage offers, and it would be very difficult for some clergypersons (Catholic priests for example) to sign civil union licenses.

Second, more than 80 per cent of same sex couples came from other states. Whereas nearly one third of gay and lesbian Vermonters who entered a civil union chose a religious civil union, only $11 \%$ of out-of-staters opted for it. With this exception, the population who had a "civil" civil union and the population who had a religious civil union are quite similar. 9 per cent of gay or lesbian couples are of mixed races. 14 per cent of these couples as well as 14 per cent of the one-race couples chose to have a religious civil union. The "civilly unioned" population is highly educated. 87 per cent have been to college, and the odds of having a "religious" civil union increases - but only by 4 points - with the education of "party A".

\section{TABLE 2 ABOUT HERE}


The civil union license application form asks parties " $\mathrm{A}$ " and "B" for the number of previous marriages and civil unions. Since no dissolution of civil union had taken place at the time of my research, the number given by the members of the couples was the number of previous heterosexual marriages. 38 per cent of the civil unions involved at least one divorcee (or widow): 26.4 per cent of women (1244 out of 4716) have been divorced or widowed (16.4 per cent of men). The recently released PUMS data shows a similar discrepancy between lesbian and gay couples: female same-sex couples are more likely to have been (heterosexually) married before entering a same-sex couple (source: 2000 U.S. Census, Public Use Microdata $5 \%$, released autumn 2003).

\section{TABLE 3 ABOUT HERE}

Whereas heterosexual re-marriages are less likely to be religious than first marriages, the proportion of religious civil unions (already small) does not decrease when the number of previous heterosexual unions increases.

To conclude: if the choice of a religious civil union is a religious consumption, then -contrary to Sherkat's finding -- gender does not have much influence. Nor does race or sexuality: formerly "heterosexually married" people and people for whom civil union is the first state-sanctioned union are as likely to enter a religious civil union. The state of residence and education seem to have more influence.

\section{Who are the ministers?}

What goes on the "supply side"? There must be pastors, priests or rabbis to perform civil unions, and to sign the civil union license. I managed to find the denomination of the religious officiants from their name and address on the civil union licenses.

\section{TABLE 4 ABOUT HERE}

160 ministers have performed 521 civil unions over the first eighteen months. Female and male ministers do not seem to be involved in a radically different way, but women performed more civil unions than men (3.5 civil unions in average, whereas male ministers performed 3.1 civil unions). 


\section{TABLE 5 ABOUT HERE}

The results of this table are both surprising and well known. The Unitarian-Universalists, one of the most liberal American denominations, declared in 1984 that same-sex unions could be performed by UUA ministers. They have been on the market for nearly 20 years. Furthermore the Unitarian-Universalists are not only involved as an institution, but their institution also includes highly involved ministers, some of whom will perform ceremonies not only in their church building but wherever people want to have a ceremony (Coulmont 2003).

The United Church of Christ and the Episcopal Church are very close: between one quarter and one third of their Vermont pastors ${ }^{2}$ have celebrated at least one civil union, during the first eighteen months of the implementation of the civil union law. Presbyterians, Lutherans, American Baptists, United Methodists are then tucked into a very small niche, and only a handful of pastors performed civil unions. According to my records, only three civil unions were performed by UFMCC pastors, even if this gay and lesbian denomination performs "holy unions" since 1968.

With those numbers, the churches could be ranked according to their degree of "liberalism", with Unitarians on the top and Roman Catholics on the bottom. But this scale would not include a number of civil unions performed by "non-mainstream" ministers. Small religious movements, various cults, and self-proclaimed ministers perform one quarter of all civil unions. Mail-order ministers, at least twelve of whom have been performing civil unions, are an interesting group: most of them do not advertise their ministerial credentials and will perform civil unions for friends who know they can sign the civil union license and bring a touch of spirituality along. In some cases, those ministers are lay members of mainstream Protestant congregations (United Methodist, Presbyterians) who choose to be ordained through the internet because they cannot officially perform marriages if they do not have credentials.

\section{Description: A McMarriage?}

The creation of civil unions has given birth to a tiny market whose roots are in the marriage business, which is, in Vermont, a new and thriving industry catering in part to out-of-staters. Vermont marriages are on the verge of being both "secularized" and "commodified". 
Theories of secularization are widely opposed in the U.S., and many elements can be construed as showing a continuing role of religion in public as well as private spaces (Warner, 1993). Vermont may be, in this particular instance, a counter-example. From 1960 to 1988, the proportion of religiously performed first marriages in the "Marriage Registration Area" states (M.R.A.)"3 fell by 9 per cent, whereas in Vermont it fell by 23 Per cent. And in several states (like Georgia) the proportion of religious marriages has grown. In 2002 in Vermont, less than 48 per cent of first marriages were performed by ministers.

\section{FIGURE 1 ABOUT HERE}

Marriage has also been "commodified": since the beginning of the 1980s, the state of Vermont has been making access to marriage easier. Marriage used to be surrounded with obstacles (blood tests, 3-day waiting period) which were eliminated between 1980 and the beginning of the 1990s. As a consequence, more out-of-staters came to Vermont to "tie the knot": they were only 12 per cent in 1980, and 36 per cent in 2000. A small wedding industry blossomed. In 1990, the Burlington Free Press" "Business section" published an article entitled "The Bride Biz": "Signs of a thriving wedding industry are everywhere. An unprecedented number of bridal shops are opening, reception rooms are booked a year in advance." The very same year the first "Vermont Wedding Guide", a magazine-like guidebook for out-of-staters was published. In the 1995 edition's preface, Howard Dean, the Vermont governor, wrote: "Thank you for choosing to have your wedding in Vermont" most recent edition includes one page for gay and lesbian fiancés, who want to have a civil union in Vermont.

Marriage has now been included in Vermont's tourism economy, and civil unions can be seen as a new outlet for a marriage industry: a few ministers tried to get a part of this business.

Some ministers have affiliated their services to websites or have advertised their services in the local gay and lesbian press (Out in the Mountains, Vermont's LGBT newspaper, carries a section on civil union officiants). At least one minister came to Vermont after living in Las Vegas. The website gayweddings.com proposes civil union packages for couples who want to go to Vermont to celebrate their commitment. At the bottom of one page, the couple can contact an officiant, who will "help couples create and celebrate individualized Civil Unions by gaining an understanding of the partners' intentions, life experiences, and spiritual language. He drafts Ceremonies that accurately convey a couple's deep feelings \& 
commitments." This website is pushing the commodification of marriage to the level of "macdonaldization" described by George Ritzer (1993), and seems to push Vermont towards Reno or Las Vegas.

\section{FIGURE 2 ABOUT HERE}

In this first part, I considered a religious civil union to be either a religious "consumption" or an element in a commodified touristic economy. This outlined a pragmatic exit from conflict: "Culture wars" make no economic sense. But if, from the outside, religion can appear to be a marketplace, from the inside, when I study the work of pastors, religion appears in dialectic tension with the market.

\section{Performing civil unions}

The market is not the only place for a conflict to die out. There are several other ways to legitimate an innovation: following Max Weber, I identify three ways: through charisma, through tradition or through a reference to the legal order. In Vermont the "legal order" took a significant importance. By various appeals to the legal order, ministers and churches sought to accommodate to the new law.

"Accommodation" is not to be construed as a derogatory term; the whole state of Vermont had to adapt, to accommodate to the new law on civil union. Even the Roman Catholic Church after organizing demonstrations, and sending Bishops' letters to the parishes, is now trying to live with civil unions, without performing any -- at least officially. I studied more closely ministers who have performed civil unions since July 2000, and how they have contributed to the routinization of civil unions in Vermont. I will rely here on twelve interviews conducted with Vermont ministers between January and May 2002 in Vermont.

\section{Not a moneymaker, but a gift}

In interviews, pastors insist that civil unions are not (only) a moneymaker but that their aim is to bring people back to church. The strong influence of Unitarian ministers on civil unions can be set in the context of a denominational policy best described by the slogan: "You came for a wedding and you found a church", which implies that wedding is a first step toward church socialization. 
I found a second example in an interview with a lesbian Episcopal priest, who recently left her job in a large church to become a yoga instructor. In this interview, she describes the difference between her job at the church and her performing civil unions now. When talking about her work in the church and describing the money circuit, she used expressions such as "we didn't charge parishioners", “we are giving back to them”, "it wasn't a charge, it was a donation to the priest", "a thank-you gift"... And when she talked about officiating at civil unions ceremonies now, she used "outside [...] it's an hourly fee", "I'm a professional and I'm essentially charging for my time".

In this interview, she tries to describe the church as a space where money cannot be considered as a standard for the amount of work, but as a way to say "thank you". On the contrary, outside of the church, when she is performing civil unions (which she continues to do as an ordained Episcopal priest), she asks for a fee.

Marriages, and civil unions, need to be understood as a gift in a network of gifts and countergifts that enable a congregation to exist outside of the economic marketplace. To insist only on the commodification of marriage or a religious "marketplace" would not allow the sociologist to understand the meanings and feelings pastors put into marriage. Nearly one third of the Vermonters who entered a civil union chose a religious one: they were already known to the congregation and linked by all kinds of relationships to their pastor or rabbi or priest.

\section{Not a prophetic stand but the enactment of a law}

Pastors performing same-sex unions outside of Vermont often rely on charisma or emphasize their role as prophetic: what they are performing now will be accepted sooner or later. To quote a homily from an Episcopal priest in New Jersey, during a same-sex commitment ceremony:

This evening we have come to this sacred place, where people for the past 85 years have celebrated their commitments to each other, have exchanged vows of fidelity and have sought God's blessing upon them. What we do this evening stands in a long tradition and is no different from what has gone before, apart from the myopia of the State of New Jersey which refuses $y$ (sic: yet) to recognize the legality of this marriage. But, that will change one day. [Homily, New Jersey, Episcopal church, 2002, personal communication] 
In the homily, the priest calls the ceremony a "marriage" and attacks the myopia of the state of New Jersey. He connects the ceremony to the "long tradition" of (different-sex) marriages performed in his church since it was built.

On the contrary, in a homily pronounced in Vermont, "liberal" ministers -- who pushed toward full marriage rights for same-sex couples -- accepted a compromise and pushed toward accommodation:

Welcome to [...Name of place...] and to this joyful celebration of A... and H...'s Holy and Civil Union. [...] Holy and Civil Union is the joining of two individuals in heart, body, and mind. It's intended for their mutual joy, for help and comfort in good times and bad, and for the nurturance and manifestation of love in the lives of all whom they encounter. And yet love, real love that's nurturing and mutually supportive, that's committed to the long haul... that kind of love is not easy to find. [Homily, Vermont, Episcopal Church, 2002, personal communication]

In the homily, the "civil union" is called a "Holy and Civil Union", joining Church and state in one expression. The event is no longer described as prophetic. Further interviews with pastors point in the same direction: civil unions are described as an enactment of a law.

\section{How not to vote}

After the legislature passed the civil unions law, pastors struggled with the willingness of their congregation to allow civil unions. A few churches already had a policy for same-sex unions, but a great number never had a request for such a ceremony, and no policy, even if several same-sex couples were members. The debate that took place from January to May 2000 and during the 2000 legislative election campaign, was structured around intense political ideas about the goodness or badness of civil unions. Some liberal pastors, especially congregationalist (UCC) ones, did not want to see this debate spread into their own congregation, and they tried to avoid formal votes by all means, in order not to alienate blocks of parishioners.

This "no-vote strategy" is both an exit from conflict and a way to adjust their church to civil union: it is no longer described as a political topic but as "a part of the cultural landscape" (Sneyd 2002: 1). The law of the land permeates the law of the church. 


\section{How to play with the limits}

Akin to the "no vote" strategy, a number of practices push civil unions to the margins which are less visible to the whole congregation. One can describe it as a form of "traditionalization" of civil unions: they are performed outside of formal rules, and are slowly legitimated because they are performed.

One way is to celebrate civil unions for out-of-staters outside church building, keeping the sanctuary for members of the congregation. Another strategy is to perform civil unions on the minister's free time, or to ask retired pastors to perform civil unions. A third strategy is used in denominations where pastors can lose their credentials if they perform "homosexual unions". They do not sign the license:

I participated in a civil union but not presided at it... for a couple who's member of my church. And that was the way I could be present and support them. [The justice of the peace and myself] took part in the service. He's the one who signed. I've not done a service where I signed the license. [...] I could be subject to being brought up on charges, 'cause actually our book of discipline says "clergy shall not perform holy union services or..." [...] So it was a civil service, which I was asked to help frame in some ways. But the service itself wasn't drawn from our book of worship, for example. I guess the limit for me was... I didn't feel that I could be the one who lead them in the vows and then sign the license. Other than that, I was glad to participate.

\section{How to do the "write" thing}

Stealthy practices are in tension with the bureaucratization of civil unions, itself a powerful accommodation principle. It involves the swarm of written forms that are routine in contemporary life. Civil unions, stemming from the state, are a written category: lawsuits, legislative debates, laws, licenses, etc. were necessary for civil unions to exist. As the anthropologist Jack Goody once showed (Goody, 1977), things put in writing are "crystallized": orally, one can say that a tomato is a vegetable, and later that it is a fruit. But in a table or a list, one has to put the tomato in a specific place.

When a civil union license is written down and recorded somewhere, it is crystallized as a civil union, not as a marriage. And it becomes an element that can be computed, associated with others, injected into the whole statistics system. Statistics are not only a way to describe the world, but a way to elaborate an image of the world and to "naturalize" this social world. 
The bureaucratization of denominational life forced some churches to accept civil unions, as the following anecdote shows:

There was a member of this parish who is lesbian and was getting a license to administer a chalice on Sunday morning from the diocese. And she had to fill a form, "single, married, divorced, widowed" and this was in September of $2001 \ldots$ and she was really offended because she's a partnered lesbian, so she created her own box, "partnered" and mailed it back. And the secretary at the bishop's office [...] called and wanted to clarify what she had written. And Chris, this parishioner - that was just marvelous - she said: "I can't believe... you, in the State of Vermont, you don't have your forms updated!" and what the secretary tried to defend, was that it was an old form [...] What Chris was really angry about was that the diocesan office was not in compliance with the law. And so, therefore she felt empowered, by virtue of her status as a woman ... as a partner in a civil union, to confront the diocesan staff-person and said "My church welcomes me, and the bishop is on record saying that I'm welcomed, and your paperwork does not mean that." [interview, January 2002]

Another physical space where civil unions are recorded is the "parish register", usually an old book, where baptisms, marriages and funerals are recorded. The origin of these books lies in the European parish registers, in countries with established churches.

Some churches had already recorded their registers on computer files. In one congregation, this was done for the one-hundred-and-fifty year anniversary and, in this computer database, it was fairly easy to add a new cell, "civil union". Some other churches still had the big old book, where the couple is described as "bride" and "groom" and where the parents have to sign alongside their children:

We have a parish register, where we record baptism, funeral, weddings and civil unions. [...] These are books that are printed for God knows how long... What we did is we divided the marriage section into marriages and civil unions. And we just pasted over... you know... we printed out some computer "CIVIL UNION" and [...] then changed "bride" and "groom", 'cause there is sexist... I think we just wiped that out... and then, what it says, you know.. "parents of groom" and "parents of bride" we just made it gender neutral... but it's the same exact information. [interview, may 2002]

In this church civil unions are constructed as a separate form of union, close but not quite similar to marriage. Whereas the pastors interviewed said that civil union or marriage is all 
the same when it comes to the church, then, by focusing on the church register, the same pastors had to put civil union into the "civil union" category. Even Unitarian-Universalist ministers, for whom no accommodation seems to be necessary, had to accept a "civil union" category.

The marriage ceremony itself generates nowadays tons of paper: the license, the invitations, and the small booklet given to those who will attend the ceremony. This self-published brochure often features an outline of the service. Sometimes, it is considered as an important part of the scene and expensive ones are professionally printed. Can the ritual used for civil union be the marriage ritual?

We were told by our bishop in the Episcopal Church, when the civil unions were passed, that obviously we couldn't use the marriage rite of the Episcopal Church. Because the Legislature had been very clear about saying: this is not marriage, this is something close, but not quite the same. [...] So our Bishop said "you can't use the marriage rite of the Prayer Book."

The practices above (setting civil unions outside of the economic realm, choosing not to vote, placing civil unions in marginal spaces or putting them in bureaucratic forms) have contributed to a swift routinization. The civil union law has not only created civil spaces... where gay and lesbian couples could have their union recognized, but has also created religious spaces.

\section{Conclusion}

Following an intense cultural conflict, the implementation of civil unions was simultaneous with a speedy accommodation. Two explanations are provided in this article. First, civil unions of the religious type, understood as a religious consumption, provide incentives for an economic routinization. Second, in a dialectic tension with the state and its legal order, ministers tried to downplay the legal innovation.

Same-sex marriage does not necessarily imply a "culture war". Same-sex marriages, here civil unions, are routinely performed by pastors in the U.S. and, in the case of Vermont, have become part of the state's statistical system. Rapidly routinized, same-sex unions seem to follow the very path divorce took a few decades ago. At first, Protestant churches were against divorce, then they established guidelines to deal with divorced persons who wanted to 
be re-married by clergymen, and finally absorbed first marriage and remarriage into a single category.

\footnotetext{
${ }^{1}$ I would like to thank Scott Thumma, Wendy Cadge, Julien Amoretti and Camille Robcis for their help.

${ }^{2}$ I compared with the number of UCC and episcopal congregations in Vermont and informations given by the Episcopal Church Directory.

${ }^{3}$ The U.S. does not gather national numbers for marriages. Only Marriage Registration Area states send numbers to the National Center for Health Statistics (NCHS). This M.R.A. varies from year to year, as some states enter and some leave it. Those numbers are no longer published by the NCHS.

${ }^{4}$ Burlington Free Press, 27/12/1995, 1A and 08/05/2000, Business section, 1. See also the statistics from the Vermont Department of Health, http://www.state.vt.us/health/_hs/pubs/2001/vitals/toc.htm (may 2002)

${ }^{5}$ www.gayweddings.com

${ }^{7}$ Numbers differ from those in the previous Tables: they are numbers gathered by hand at the Vermont Department of Health office in Burlington.
} 


\section{Bibliography}

BERNSTEIN, Mary (1997) "Celebration and Suppression: The Strategic Uses of Identity by the Lesbian and Gay Movement”, American Journal of Sociology, 103(3): 531-565.

BERNSTEIN, Mary (2002) "The Contradiction of Gay Ethnicity: Forging Identity in Vermont" in D. Meyer, N. Whittier and B. Robnett (eds) Social Movements: Identity, Culture and the State, New York: Oxford University Press.

CONROY, William J. (1990) Challenging the Boundaries of Reform: Socialism in Burlington. Philadelphia, PA: Temple University Press.

COULMONT, Baptiste (2003) “Géographie de l'union civile au Vermont”, Mappemonde, 71: 13-18 [to be translated and published in 2005 in the Journal of Lesbian Studies]

COUSER, Richard B. (1993) Ministry and the American Legal System: A Guide for Clergy, Lay Worker, and Congregations, Minneapolis, MN: Fortress Press.

GOODY, Jack (1977) The Domestication of Savage Mind. Cambridge, UK: Cambridge University Press.

JOHNSON, Greg (2000) "Vermont Civil Unions: The New Language of Marriage", Vermont Law Review, 25(1): 15-59.

PLECK, Elizabeth (2000) Celebrating the Family: Ethnicity, Consumer Culture, and Family Rituals. Cambridge MA: Harvard University Press.

RITZER, George (1993) The McDonaldization of Society: An Investigation Into the Changing Character of Contemporary Social Life. Thousand Oaks, CA: Pine Forge Press.

SHERKAT, Darren E. (2002) "Sexuality and Religious Commitment in the United States: An Empirical Examination”, Journal for the Scientific Study of Religion 41(2): 313-323.

SNEYD, Ross (2002) "Elections appear to guarantee civil unions' future in Vermont". Rutland Herald. November 24: 1.

WARNER, R. Stephen (1993) "Work in Progress Toward a New Paradigm for the Sociological Study of Religion in the United States", American Journal of Sociology 98(5): 1044-1093.

Baptiste CoUlmont is an alumnus of the École normale supérieure and studied Sociology at the EHESS (Paris). After three years in New York, he recently defended his dissertation entitled "May God Bless You!": Religious Same-Sex Marriages in the U.S. His academic interests include gay and lesbian studies, sociology of law and sociology of religion. E-mail: coulmont@ens.fr 
Figure 1: Proportion of religious and civil marriages in Vermont

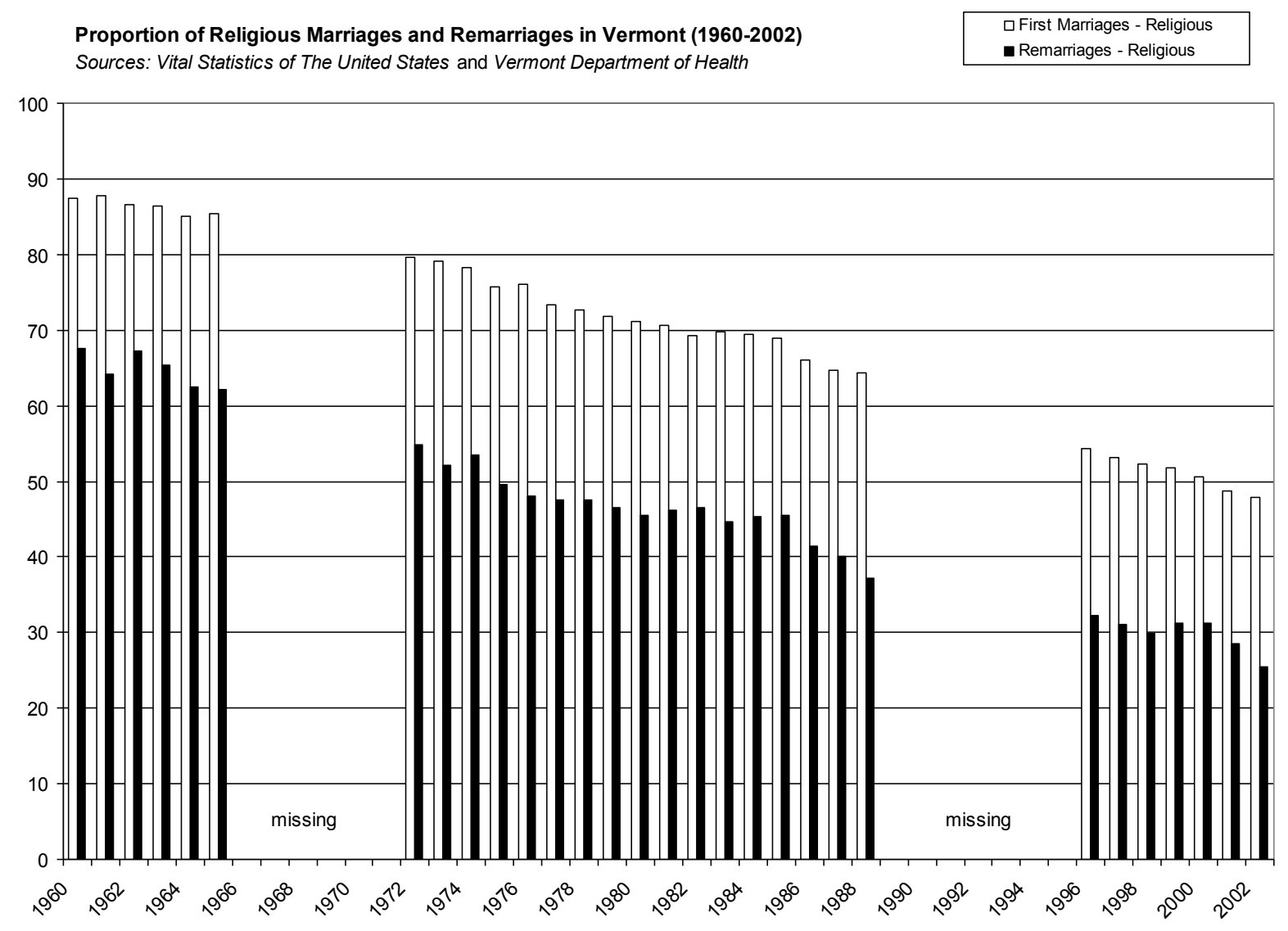

Table 1: Distribution by gender and by type of ceremony, 31/12/2001 (source: Vermont Department of Health)

\begin{tabular}{lll}
\hline & "Civil” civil union (proportion) & "Religious" civil union (proportion) \\
\hline Women & $2013(85.4 \%)$ & $345(14.6 \%)$ \\
Men & $1044(86.5 \%)$ & $165(13.6 \%)$ \\
Total & 3057 & 510 \\
\hline
\end{tabular}


Table 2: Education and type of ceremony for "party A" (source: Vermont Department of Health)

\begin{tabular}{lll}
\hline & $\begin{array}{c}\text { "Civil” civil union } \\
\text { (proportion) }\end{array}$ & $\begin{array}{l}\text { "Religious" civil union } \\
\text { (proportion) }\end{array}$ \\
\hline Elementary or secondary education & $402(88 \%)$ & $55(12 \%)$ \\
Some college & $1406(86.1 \%)$ & $227(13.9 \%)$ \\
Graduate school & $1231(84.4)$ & $227(15.6 \%)$ \\
Total (without « unknown ») & 3039 & 509 \\
\hline
\end{tabular}

Table 3: Number of unions and type of ceremony for "party A", 31/12/2001 (source: Vermont Department of Health)

\begin{tabular}{lcl}
\hline & “Civil" civil union (proportion) & $\begin{array}{l}\text { "Religious" civil union } \\
\text { (proportion) }\end{array}$ \\
\hline First union & $2373(85.73 \%)$ & $395(14.27 \%)$ \\
One or more previous marriage & $676(85.79 \%)$ & $112(14.21 \%)$ \\
Total & 3057 & 510 \\
\hline
\end{tabular}

Table 4: Officiants by gender (source: Vermont Department of Health) ${ }^{7}$

\begin{tabular}{lll}
\hline Gender & Number of "religious" C.U. $(\mathbf{N}=\mathbf{5 2 1})$ & Number of ministers $(\mathbf{N}=\mathbf{1 6 0})$ \\
\hline Female & 270 & 78 \\
Male & 251 & 82 \\
\hline
\end{tabular}

Table 5: Officiants' Number and Denomination (source: Vermont Department of Health)

\begin{tabular}{lll}
\hline Denomination & $\begin{array}{l}\text { Number of civil } \\
\text { unions (N=521) }\end{array}$ & $\begin{array}{l}\text { Number of ministers } \\
\mathbf{( N = 1 6 0 )}\end{array}$ \\
\hline Unitarian-Universalists & 233 & 23 \\
United Church of Christ (UCC) & 70 & 33 \\
Episcopal Church & 49 & 23 \\
Jewish & 24 & 13 \\
American Baptists & 13 & 7 \\
Presbyterian Church & 7 & 4 \\
\hline
\end{tabular}




\begin{tabular}{lll}
\hline United Methodist Church & 3 & 3 \\
Lutheran Churches & 4 & 3 \\
Disciple of Christ (Christian Churches) & 3 & 1 \\
Metropolitan Community Churches & 3 & 3 \\
Others: & 3 & 3 \\
$\ldots . .$. pagans & 19 & 5 \\
$\ldots . .$. spiritualists (Church of Spiritual science...) & 21 & 13 \\
$\ldots . .$. ."mail order" (Universal life church, universal & 21 \\
brotherhood church...) & 41 & 3 \\
$\ldots . .$. .interfaith", "non denominational” & 10 & 7 \\
$\ldots . .$. varia (witch, zen, yoga, eckankar, unity \\
church...)
\end{tabular}


Figure 2: gayweddings.com

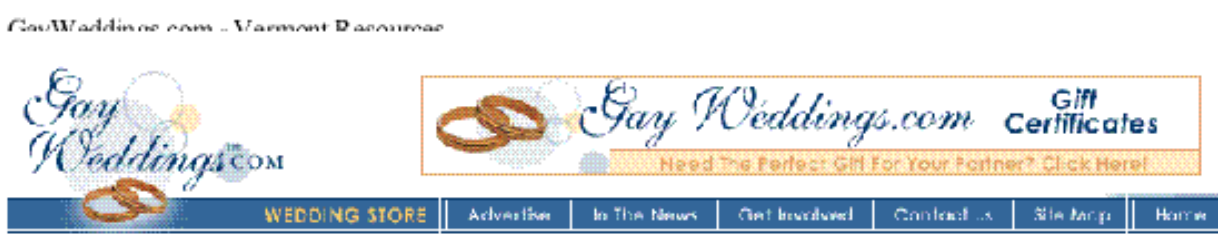

A Complete Ceremony Package for the Wedding Couple Mountainside Hide-Away
in Northern Vermont

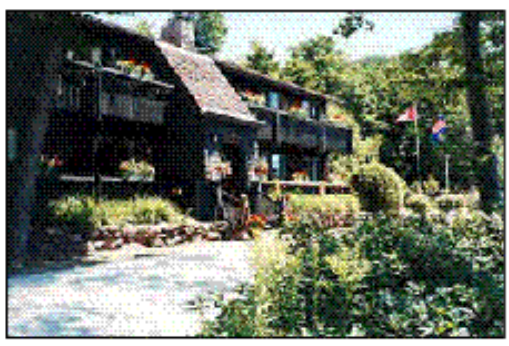

Located 2,000 ft. abore the valley floor, this Inn offers the most panoramic views and sunsets in Vermont. Sit back and relex in an unhumed atmosphere or enjoy 6,000 pristine private acres, which feature tennis courts a cry stal dear swimming pool, and trails that are perted fur hikn, biking, horse-back riding or nature tours. Centrally

\section{ORDER PACKAGE}

Call Us With Questions (215) 862-0977
All of the following are included in your Civil Union Package For Two:

Two-night Lodging with Full Breakfast and Candlelit Dinner both nights Private Civit Union Ceremony in a Garden or Woods setting, or in our Parior

Downhill Skiing or Cross Country

included in Winter

Picnic Basket, Bike Rental, or Golfing is

included in Spring/Summerif all

SUPER DELUXE Room wf Vermont Fire Store

Private Hot-tub, \& Champagne

Total Package Cost: $\$ 883$

$\$ 269$ Non-Refundable Deposit is required to ORDER PACKACE

One of GayWeddings.com Top Picks!

You can bring additional wedding guests - call for rates Need Help Planning A Larger Wedding Ceremony?

You can have up to 50 Guests at this inn

Visit our Sister Site at mow.GayWeddingPlanners.com

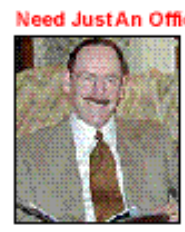

Rew. Dr. Peter W. Denny

r. Denry is an ordained Unitarian Universalist minister. He is evailable to help couples

ceate and celebrate individualized Civil Unions by gaining an understanding of the

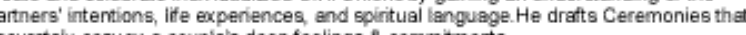

feep feelings \& commitmerts

RevDrbennyearadWeddings.com

SEE OTHER INNS > Vermont Civil Unions_... $\quad$ Go

\section{Biographical description:}

\footnotetext{
${ }^{7}$ Numbers differ from those in the previous Tables: they are numbers gathered by hand at the Vermont Department of Health office in Burlington.
} 